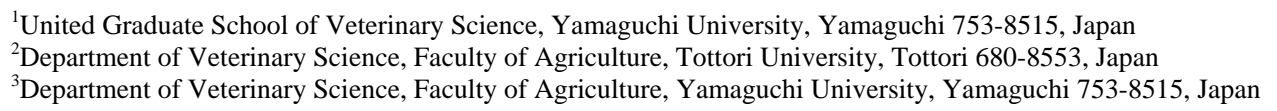

AKIHIRO KURIHARA ${ }^{1}$, JUNJIRO SEKINE ${ }^{2}$, MITSUGU HISHINUMA ${ }^{2}$, TATSUYUKI SUZUKI ${ }^{1}$ and TAKESHIGE OTOI ${ }^{3}$

\title{
Influence of recipient dams of different breeds on performance of Japanese Black calves produced by embryo transfer
}

\begin{abstract}
To clarify the effect of breed of recipient dams on the performance of calves produced by embryo transfer(ET), a total of 35 ET-calves were divided into 4 groups by the breed of recipient of Holstein-Friesian dams (HF), crossbred (Holstein $\times$ Japanese Black) dams (F1), Japanese Black dams (JB) and also JB dams without colostrum but received an artificial colostrum as a negative control (NC). Twenty calves produced by artificial insemination to JB dams were also provided as a positive control (PC). Calves in JB, HF, F1 and PC were placed with their dams for the first 7 days of age. Those in the NC group were kept in an individual pen. All calves were moved to individual pens on day 8, and were given the same commercial milk replacer. Calves were weaned at 61 days of age. Mean live weights at birth were not significantly different among groups except for calves of HF that were greater than other groups $(\mathrm{p}<0.05)$. Mean daily gains also showed no significant differences among groups including PC and NC. All calves were in good healthy condition, which was also supported by changes in the level of blood parameters, irrespective of the breed of their dams. It is concluded that there was no appreciable effect of the breed of recipient dams on calf performance. The artificial colostrum powder feeding did not show any adverse effect on the performance of ET-calves, although serum protein and globulin tended to be lower.
\end{abstract}

Key Words: embryo transfer, calf , breeds of dams, colostrums, body weight, blood contents

\section{Zusammenfassung}

Titel der Arbeit: Einfluss der Rasse der Empfängertiere auf die Leistung von ET-Kälbern der Japanischen Schwarzen Rasse

Um den Einfluss der Rasse der Empfängertiere auf die Leistung von ET-Kälbern zu analysieren, wurden insgesamt 35 ET-Kälber in 4 Gruppen nach der Rasse der Empfängertiere von Holstein-Friesian (HF), mischrassigen Muttertieren (Holstein x Japanese Black) (F1), Japanese Black Muttertiere (JB) sowie JB ohne Kolostrum, gefüttert mit einem künstlichen Kolostrum, als eine negativ Kontrolle (NC) verteilt. Zwanzig Kälber, die aus der künstlichen Besamung von JB Muttertieren stammen, wurden auch als positiv Kontrolle (PC) ausgewählt. Während der ersten 7 Tage nach der Geburt wurden die Kälber der JB, HF, F1 sowie PC bei ihren Müttern gehalten. Die Kälber der NC Gruppe wurden einzeln gehalten. Alle Kälber wurden ab dem 8. Tag individuell gehalten und mit handelsüblichem Milchaustauscher aufgezogen. Die Entwöhnung der Kälber erfolgte im Alter von 61 Tagen. Das durchschnittliche Geburtsgewicht zeigte keine signifikanten Unterschiede zwischen den Gruppen, nur die Kälber der HF waren schwerer als die anderer Gruppen $(\mathrm{p}<0.05)$. Kein wesentlicher Unterschied wurde auch bei der durchschnittlichen täglichen Zunahme des Körpergewichtes bei den Gruppen, einschließlich PC und NC, festgestellt. Alle Kälber waren in einem guten Gesundheitszustand. Dieser war auch bei Veränderungen im Blutparameterspiegel unabhängig von der Rasse der Mütter. Die Ergebnisse zeigten, dass kein Einfluss der Rasse der Empfängertiere auf die Leistung der Kälber nachgewiesen werden konnte. Die Fütterung mit künstlichem Kolostrum hatte keinen negativen Einfluss auf die Entwicklung der ET-Kälber, obwohl eine fallende Tendenz bei Eiweiß und Globulin im Blutserum ermittelt wurde.

Schlüsselwörter: Embryotransfer, Kalb, Rasse der Empfängertiere, Kolostrum, Körpergewicht, Blutinhaltsstoffe 


\section{Introduction}

Importance of the colostrum has been well documented for the consideration on the supply of the immune globulin to a calf (BRAUN et al., 1982; MORIN et al., 1997; WEAVER et al., 2000). The supply of the immune globulin from the dam to neonatal calves is termed passive transfer (WEAVER et al., 2000). Calves with failure of passive transfer (FPT) have increased risks to the newborns concerning the preweaning morbidity and mortality compared to those with adequate passive transfer (WEAVER et al., 2000). Therefore, it is important for calves to be given an adequate amount of immune globulin through the feeding of colostrum from their dams. The concentration of immune globulin in colostrum has been demonstrated to show a significant difference among breeds of dairy cows (MULLER and ELLINGER, 1981; TYLER et al., 1999) among which Holstein had the least concentration of immune globulin (MULLER and ELLINGER, 1981; TYLER et al., 1999). GUY et al. (1994) demonstrated that the concentration of immune globulin was similar in prepartum mammary secretions for both beef and dairy cattle. For 2 weeks prepartum, however, dairy cattle showed a dramatic decrease in serum IgG concentration and a concomitant increase in serum $\alpha$-lactalbumin concentration relative to that of the beef cattle. Therefore, dams of dairy breeds may produce colostrum with low concentrations of immune globulin for their offsprings resulting a higher risk for calves with FPT. ROBINSON et al. (1988) reported that mortality rates of calves with FPT increased in the postweaning period as well as preweaning period compared to the normal ones.

In the beef production in Japan, the technique for embryo transfer (ET) has been increasingly utilized to produce beef calves by using dairy cows. There is a rumor among beef producers in Japan, however, that the calves born from dams of dairy breeds by ET technique have a weak constitution and require a delicate nursing management to raise them. So far, there is no scientific evidence to support the rumor or deny it. Holstein cows have been utilized as major recipient dams of dairy breeds in many ET techniques. In addition, the conventional system for calf raising allows calves to suckle milk naturally from their dams for several days. Naturally suckled calves may have a greater risk of FPT (WEAVER et al., 2000) because of inadequate intakes of colostrum and IgG mass (BESSER et al., 1991; STOTT et al., 1979). To overcome this possibility, feeding of artificial colostrum powder has been practiced at parturition of Japanese Black calves.

WEAVER et al. (2000) have reported, however, that analysis of results presented by TYLER et al, (1998) substantiated that the majority of calves (77\%) would have survived under the condition of complete FPT which has been designated as a serum protein concentration less than $4 \mathrm{~g} / \mathrm{dL}$. TYLER et al. (1998) reported that optimal survival was observed in calves with a serum protein concentration over $5.5 \mathrm{~g} / \mathrm{dL}$. This level was already previously suggested to be a level which lowered the health risk of dairy calves or alternatively a serum IgG concentration to $1.5 \mathrm{~g} / \mathrm{dL}$ (BOYD et al., 1974; IRWIN, 1974). Serum $\gamma$-Glutamyltransferase activity was also utilized to predict the concentration of immune globulin (PARISH et al., 1997; WILSON et al., 1999).

Therefore, it has significant importance to clarify whether recipient dams of dairy breeds for ET technique have some adverse influence upon the performance of calves in the neonatal period. It is also important to know that feeding of the artificial colosrtum powder may release calves from constraints of FPT. 
The present study was purposed to determine the influence of recipient dams of 3 different breeds on daily gain, health, and selected blood metabolites of Japanese Black calves in the suckling period and the efficacy of feeding of artificial colostrum powder to reduce the risk of failure of passive transfer (FPT).

\section{Materials and Methods}

\section{Animals}

Animals used in the present study were a total of 55 calves (30 male and 25 female) of Japanese Black breed produced in the Tottori Prefecture Animal Husbandry Experiment Station. Of which 35 calves produced by embryo transfer were used as an experimental group. Twenty calves were produced by artificial insemination and were used as a positive control group (PC). The experimental group was divided into 4 groups by the breed of recipient dams as follows; 1) 6 calves from Holstein-Friesian dams (HF), 2) 14 calves from crossbred (Holstein $\times$ Japanese Black) dams (F1), 3) 11 calves born from Japanese Black dams (JB), and 4) 4 calves from JB dams without colostrums but received an artificial colostrums as a negative control (NC).

\section{Management}

All calves were supplemented with a commercial colostrum supplement (Mother-Milk, Nosan Corporation, Yokohama) at a level of $300 \mathrm{~g}$ in $900 \mathrm{ml}$ of warm water by using an esophageal feeder within 30 min. after birth. Calves in HF, F1, JB and PC were then placed with their dams for the first 7 days of age. Those in the NC group were kept in an individual pen and were given a commercial colostrums supplement 3 times a day for 3 days after birth at a level of $200 \mathrm{~g}$ at each feeding (600 g/calf/day). The supplement was diluted with 6 times of warm water at feeding. From day 4 after birth, calves were then offered a commercial milk replacer (Shin-Milk, Scientific Feed Lab., Tokyo) 3 times a day at a level of $600 \mathrm{~g} / \mathrm{calf} /$ day up to 7 days of age. All calves were moved to individual pens on day 8, and were given the same commercial milk replacer described above twice a day at a level of $600 \mathrm{~g} / \mathrm{calf} /$ day up to 45 days of age. The feeding frequency of the replacer was reduced to once a day with a level of 300 $\mathrm{g} /$ calf/day on day 46 and after. Calves were weaned at 61 days of age. Solid feeds offered were a commercial calf starter (Super-Mooreto-Hoiku, Nishi-nihon Kumiai Siryo, Kobe) and chopped $2^{\text {nd }}$ cut timothy hay starting at 7 days of age. Drinking water was offered with free access.

\section{Sample collection and analyses}

Samples of colostrum and milk from the dams were collected on the day prior to the calf actually suckling (day 0) and, 1, 3 and 7 days after calving. They were centrifuged at 3,000 rpm for 10 minutes and the supernatant liquid was collected and frozen for further analyses. Blood samples from calves were collected from the left jugular vein at the day prior to the calf suckling of colostrum (day 0) and, 1, 3, 7, 14, 21, 28, 45 and 60 days after birth. Samples were analyzed for glucose in calf plasma by using quantitative dry-spectrophotometer (FUJI DRY-CHEM, FUJI FILM, Tokyo). Samples of the calf serum and dam's milk were also analyzed for the triglyceride (TG), total cholesterol, total protein, albumin, gamma-glutamyltransferase (GGT), calcium (Ca), and inorganic phosphorus (IP) by using the same apparatus as the blood plasma. 
Apparent serum globulin was calculated by subtracting serum albumin from serum total protein. The live weight of a calf was measured on the day when the blood was sampled. Feed consumption was recorded weekly by subtracting the refusals from the quantity offered. Health status of an individual calf was recorded throughout the experimental period of 60 days.

\section{Statistical analysis}

Results were analyzed by using a statistical package of Statistix7 (2000) with the breeds of dams as a main effect. Comparison of mean values of each group at each of days of age was analyzed by Fisher's LSD using a statistical package of Statistix7 (2000).

\section{Results}

Table 1 shows mean live weight of calves of each group at birth, 7, 14, 21, 28, 45 and 60 days of age. Mean live weights at birth and at 60 days of age were significantly greater in calves of HF group than those for other groups $(p<0.05)$. Mean daily gains, however, showed no significant differences among groups including PC and NC because of a greater coefficient of variation. Mean daily gains of calves at the first week of life ranged from $0.51 \mathrm{~kg}$ for the HF group to $0.91 \mathrm{~kg}$ for the PC group. In the second week of life, it decreased to the range from $0.13 \mathrm{~kg}$ for PC group to $0.38 \mathrm{~kg}$ for HF group. From the third week, it increased gradually and reached to the level ranging from $0.63 \mathrm{~kg}$ for $\mathrm{F} 1$ and $\mathrm{NC}$ to $0.82 \mathrm{~kg}$ for $\mathrm{HF}$ at the period of 45 to 60 days of age.

Table 1

Mean live weight $(\bar{x})$ with standard deviation (S) of embryo transferred calves born from Japanese Black (JB), Holstein Friesian (HF), crossbred (F1) dams and calves produced by embryo transfer and raised by artificial colostrum supplement without nursing their dam as a negative control (NC), and those produced by artificial insemination as a positive control (PC) (Durchschnittliches Lebendgewicht $(\bar{x})$ und Standardabweichung (S) von Embryotransferkälbern aus Empfängertieren verschiedener Rassen, die mit künstlichem Kolostrum aufgezogen wurden sowie Kontrollgruppenergebnisse)

\begin{tabular}{ccllll}
\hline $\begin{array}{c}\text { breeds of dam } \\
\text { (no. of calves) }\end{array}$ & $\begin{array}{c}\text { JB }(\mathrm{n}=11) \\
\bar{x} \pm \mathrm{S}\end{array}$ & $\begin{array}{c}\mathrm{HF}(\mathrm{n}=6) \\
\mathrm{x} \pm \mathrm{S}\end{array}$ & $\begin{array}{c}\mathrm{F} 1(\mathrm{n}=14) \\
\bar{x} \pm \mathrm{S}\end{array}$ & $\begin{array}{c}\mathrm{NC}(\mathrm{n}=4) \\
\bar{x} \pm \mathrm{S}\end{array}$ & $\begin{array}{c}\mathrm{PC}(\mathrm{n}=20) \\
\bar{x} \pm \mathrm{S}\end{array}$ \\
\hline at birth & $28^{\mathrm{b}} \pm 3$ & $38^{\mathrm{a}} \pm 6$ & $30^{\mathrm{b}} \pm 5$ & $34^{\mathrm{b}} \pm 2$ & $30^{\mathrm{b}} \pm 5$ \\
7 days of age & $33 \pm 3$ & $41 \pm 6$ & $36 \pm 6$ & $39 \pm 3$ & $37 \pm 6$ \\
14 days of age & $35 \pm 3$ & $44 \pm 7$ & $37 \pm 7$ & $41 \pm 3$ & $39 \pm 7$ \\
21 days of age & $38^{\mathrm{b}} \pm 3$ & $47^{\mathrm{a}} \pm 8$ & $40^{\mathrm{b}} \pm 7$ & $45^{\mathrm{b}} \pm 4$ & $42^{\mathrm{b}} \pm 7$ \\
28 days of age & $42^{\mathrm{b}} \pm 3$ & $52^{\mathrm{a}} \pm 9$ & $44^{\mathrm{b}} \pm 6$ & $48^{\mathrm{b}} \pm 6$ & $47^{\mathrm{b}} \pm 7$ \\
45 days of age & $53 \pm 5$ & $62 \pm 11$ & $55 \pm 8$ & $58 \pm 3$ & $57 \pm 8$ \\
60 days of age & $66 \pm 8$ & $74 \pm 11$ & $65 \pm 8$ & $67 \pm 3$ & $68 \pm 10$ \\
\hline
\end{tabular}

Data in the same row with different superscripts differ significantly $(\mathrm{P}<0.05)$.

Calves have begun to ingest an appreciated amount of calf starter after 14 days of age. The intake of calf starter by calves was about $0.15 \mathrm{~kg}$ at 21 days of age, but increased gradually to about $0.8 \mathrm{~kg}$ at 42 days of age. Calves ingested the starter well over $1.0 \mathrm{~kg}$ at 49 days of age and about $1.5 \mathrm{~kg}$ at 56 days of age. There was, however, no 
significant difference in the daily quantity of the starter intake by calves among groups.

All calves were in good condition in their health status. Calves suffered from diarrhea for 1.07 days on average for the first 4 weeks of their life and for 1.05 days on average for the rest of the period. They also showed very short period of cold symptoms of coughing and nasal mucus secretion. They suffered only 1.26 days on average for the first 4 weeks of life and 0.13 days for the rest of the period. There was no significant difference among the groups regarding health records such as days in diarrhea, \% of calves in diarrhea and other health disorder described above.

The plasma glucose level averaged $57 \mathrm{mg} / \mathrm{dL}$ at birth for calves in all groups. The level almost doubled (110 mg/dL) on the first day of life and stayed at about the same evel throughout the rest of the period, except for NC group in which calves showed a decreased level of about $85 \mathrm{mg} / \mathrm{dL}$ on 45 and 60 days of age. Changes with the day after birth in serum total cholesterol and triglyceride levels were not significantly different among groups. Mean levels of serum total cholesterol and triglyceride for each group showed a fairly large variation in the course of 60-day period. The levels at birth were low (25 mg/dL for cholesterol and $21 \mathrm{mg} / \mathrm{dL}$ for triglyceride), but they were increased to $83 \mathrm{mg} / \mathrm{dL}$ for cholesterol and $54 \mathrm{mg} / \mathrm{dL}$ for triglyceride on 3 days of age. The total cholesterol level was maintained about the same level throughout the rest of the period, except for NC group in which calves showed a decreased level of about 65 $\mathrm{mg} / \mathrm{dL}$ on 45 and 60 days of age. The level of triglyceride was decreased to a level of less than $20 \mathrm{mg} / \mathrm{dL}$ on 14 days of age and recovered to the level of about $30 \mathrm{mg} / \mathrm{dL}$ in the rest of the period.

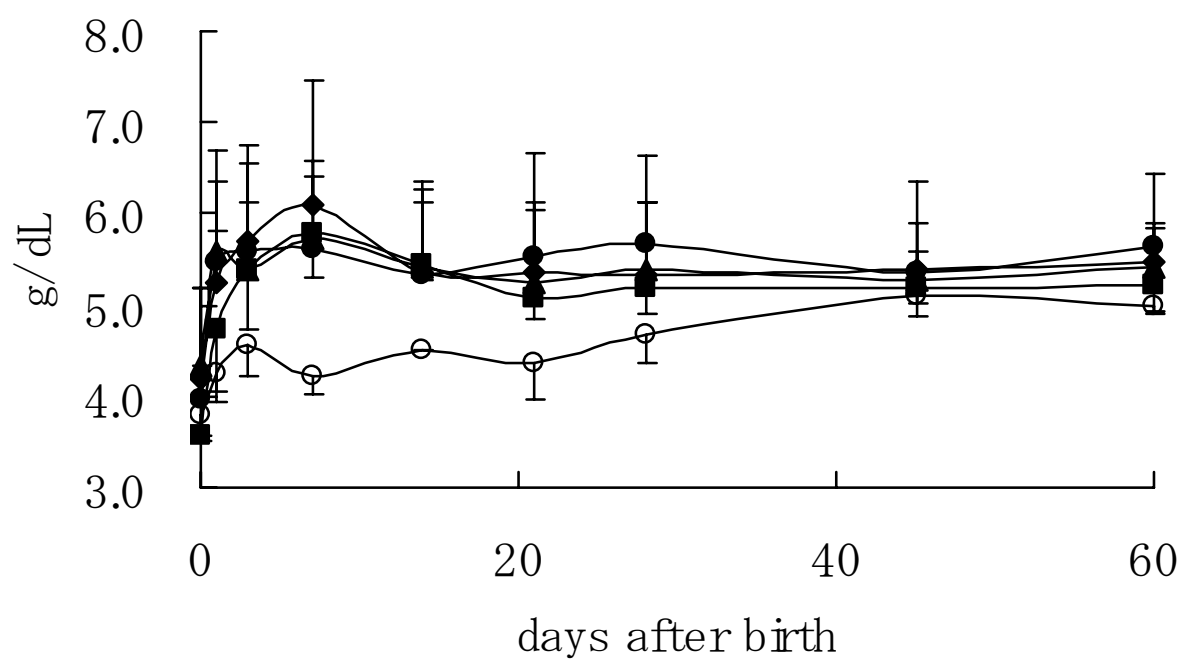

Figure 1: Changes in concentration of serum total protein in calves of Japanese Black (•), Holstein- Friesian (• ), crossbred (Holsteinx Japanese Black, $\boldsymbol{\wedge})$, negative control group $(\circ)$ and positive control group $(\bullet)$.

Fig. 1: Veränderungen des Serumproteingehaltes der Kälber aus den Versuchsgruppen während der ersten 60 Lebenstage

Figure 1 shows changes with the day after birth in serum total protein levels for calves in each group. Although there was no significant difference among groups, calves in NC group showed a lower level of serum total protein up to 28 days of age compared 
to those in other groups. The lowest level of serum total protein for the NC group was $4.2 \mathrm{~g} / \mathrm{dL}$ at 7 days of age after birth. The levels of apparent serum globulin were changed in a similar pattern to those of the serum total protein as illustrated in Figure 2. Calves in the NC group showed a lower level of serum globulin up to 28 days of age compared to those in other groups as was shown previously in the serum total protein level. Although the lowest level of serum globulin for the NC group was recorded at the level of $1.7 \mathrm{~g} / \mathrm{dL}$ at 21 days of age, the levels at 7 and 14 days of age were also lower (1.9 and $1.8 \mathrm{~g} / \mathrm{dL}$, respectively) compared to the other sampling periods.

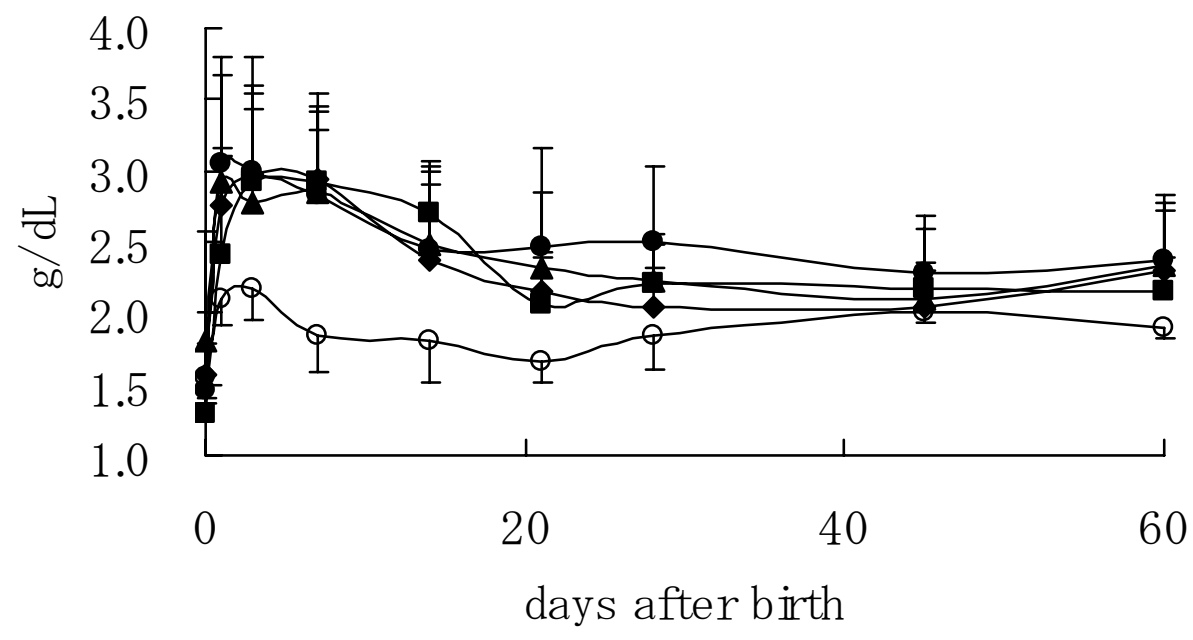

Figure 2: Changes in concentration of serum apparent globulin in calves of Japanese Black ( $\bullet$ ), Holstein-Friesian ( $(\bullet)$, crossbred (Holstein $\times$ Japanese Black, $\boldsymbol{\wedge}$ ), negative control group ( $\circ$ ) and positive control group $(\bullet)$.

Fig. 2: Veränderungen des Serumglobulingehaltes der Kälber aus den Versuchsgruppen während der ersten 60 Lebenstage

Activities of serum enzymes varied in a wide range of fluctuation throughout the 60day period. The mean value of 90 IU/L for GGT at birth increased to the peak of 2000 $\mathrm{IU} / \mathrm{L}$ at first day of age and decreased sharply toward the end of the experimental period reaching $20 \mathrm{IU} / \mathrm{L}$ at 60 days of age, except for NC. The GGT level at the first day of age for NC calves was $900 \mathrm{IU} / \mathrm{L}$ and at 3 days of age, it decreased to the level of $300 \mathrm{IU} / \mathrm{L}$. The concentration of serum calcium and inorganic phosphorus was fairly stable throughout the 60-day period. The level of calcium stayed at about $10 \mathrm{mg} / \mathrm{dL}$ and that of phosphorus started at $7.4 \mathrm{mg} / \mathrm{dL}$ at birth, reached to $10 \mathrm{mg} / \mathrm{dL}$ at 3 days of age and stayed about the same level for the rest of the period.

Milk composition for each dam group was presented in Table 2 together with the composition of diluted commercial colostrums powder given to the calves in the NC group. The concentration of the total protein in the colostrum ranged from $9.1 \mathrm{~g} / \mathrm{dL}$ for the F1 group to $14.5 \mathrm{~g} / \mathrm{dL}$ for the PC group. The total protein level was $13.0 \mathrm{~g} / \mathrm{dL}$ for commercial colostrum diluted with 3 times of warm water at birth. The level of total protein in milk was decreased to a normal level within 7 days after parturition. The level for commercial milk replacer diluted by 6 times resulted in a little lower value $(2.2 \mathrm{~g} / \mathrm{dL})$ than the natural milk produced by dams used in the present study. The concentration of apparent globulin also showed the highest value for colostrum ranging from $6.3 \mathrm{~g} / \mathrm{dL}$ for the F1 group to $10.2 \mathrm{~g} / \mathrm{dL}$ for the PC group. The globulin 
level changed in a similar pattern for those of total protein, and reached to a level of about $2 \mathrm{~g} / \mathrm{dL}$ within 7 days after parturition. The globulin level was $8.2 \mathrm{~g} / \mathrm{dL}$ for commercial colostrums powder diluted by 3 times of warm water at birth. The globulin level was $1.2 \mathrm{~g} / \mathrm{dL}$ for milk replacer in the dilution by 6 times of warm water at 7 days of age for calves. The level of calcium in the milk was the highest in the colostrum and was decreased to a level of about $160 \mathrm{mg} / \mathrm{dL}$ at 7 days after parturition. While, inorganic phosphorus stayed on an almost similar level for the first 7 days after parturition with same variation. The concentration in commercial colostrum, however, showed a little lower value than that of natural milk when it was diluted with 6 times of warm water.

Table 2

Mean nutrients concentration of milk secreted by Japanese Black (JB), Holstein Friesian (HF), crossbred (F1) dams and artificial colostrum supplement given calves for a negative control (NC) group, and dams of calves produced by artificial insemination as a positive control (PC) group (Milchinhaltsstoffe während der ersten 7 Lebenstage bei den Empfängertieren verschiedener Rassen und der Kontrollgruppen)

\begin{tabular}{|c|c|c|c|c|c|}
\hline $\begin{array}{l}\text { breeds of dam } \\
\text { (no. of observation) }\end{array}$ & $\mathrm{JB}(\mathrm{n}=11)$ & $\mathrm{HF}(\mathrm{n}=6)$ & $\mathrm{F} 1(\mathrm{n}=14)$ & $\mathrm{NC}(\mathrm{n}=1)$ & PC $(n=20)$ \\
\hline \multicolumn{6}{|l|}{ Total protein, g/dL } \\
\hline at parturition & $11.2 \pm 6.0$ & $11.8 \pm 1.4$ & $9.1 \pm 5.5$ & 13.0 & $14.5 \pm 5.6$ \\
\hline 1 day after partu. & $6.1 \pm 2.4$ & $6.9 \pm 0.2$ & $6.2 \pm 2.7$ & 6.5 & $5.5 \pm 2.7$ \\
\hline 3 days after partu. & $3.6 \pm 0.4$ & $3.7 \pm 0.3$ & $4.0 \pm 1.1$ & 6.5 & $4.0 \pm 1.0$ \\
\hline 7 days after partu. & $3.6 \pm 0.4$ & $3.3 \pm 0.8$ & $3.4 \pm 0.7$ & 2.2 & $3.5 \pm 0.3$ \\
\hline \multicolumn{6}{|c|}{ Apparent globulin, g/dL } \\
\hline at parturition & $8.3 \pm 5.9$ & $7.6 \pm 1.1$ & $6.3 \pm 4.2$ & 8.2 & $10.8 \pm 4.4$ \\
\hline 1 day after partu. & $4.1 \pm 2.1$ & $4.9 \pm 0.4$ & $3.9 \pm 2.3$ & 4.1 & $3.7 \pm 2.1$ \\
\hline 3 days after partu. & $2.0 \pm 0.6$ & $2.2 \pm 0.3$ & $2.4 \pm 0.9$ & 4.1 & $2.1 \pm 0.8$ \\
\hline 7 days after partu. & $1.9 \pm 0.9$ & $1.7 \pm 0.2$ & $2.1 \pm 0.6$ & 1.2 & $2.0 \pm 0.4$ \\
\hline \multicolumn{6}{|l|}{ Calcium, mg/dL } \\
\hline at parturition & $231 \pm 66$ & $368 \pm 106$ & $310 \pm 148$ & 184 & $240 \pm 69$ \\
\hline 1 day after partu. & $166 \pm 45$ & $265 \pm 28$ & $219 \pm 130$ & 92 & $171 \pm 48$ \\
\hline 3 days after partu. & $173 \pm 61$ & $169 \pm 26$ & $134 \pm 22$ & 92 & $180 \pm 51$ \\
\hline 7 days after partu. & $160 \pm 27$ & $165 \pm 48$ & $143 \pm 24$ & 82 & $160 \pm 28$ \\
\hline \multicolumn{6}{|c|}{ Inorganic Phosphorus, mg/dL } \\
\hline at parturition & $80 \pm 24$ & $117 \pm 3$ & $88 \pm 22$ & 98 & $85 \pm 21$ \\
\hline 1 day after partu. & $69 \pm 13$ & $86 \pm 12$ & $72 \pm 18$ & 49 & $70 \pm 12$ \\
\hline 3 days after partu. & $82 \pm 19$ & $68 \pm 10$ & $65 \pm 10$ & 49 & $78 \pm 20$ \\
\hline 7 days after partu. & $96 \pm 16$ & $59 \pm 11$ & $66 \pm 11$ & 70 & $71 \pm 15$ \\
\hline
\end{tabular}

\section{Discussion}

The standard weight for Japanese Black cattle of 60 days of age, ranged from 60.2 to $81.0 \mathrm{~kg}$ in female, and 63.7 to $88.4 \mathrm{~kg}$ in male (Japanese MAFF, 2000). The mean live weight for each group at the age of 60 days was in the range of the standard weight in male, although each group was composed of male and female calves. Therefore, all calves in the present study were assumed to grow normally to the age of 60 days, irrespective of the breed of recipient dams.

The calves in the HF group were heavier than those for other groups at birth and at 60 days of age. The body conformation of HF cows is bigger than Japanese Black cows 
(Japanese MAFF, 2000). Thus, this difference in body conformation may have caused in the difference in the birth weight of ET calves. Of the nature of dairy purpose, cows of HF breed produce milk greater than the beef breeds. For example, HF cows have shown the mean daily milk yield of $21.5 \mathrm{~kg}$ in Ireland under the pasture-based feeding (BUCKLEY et al., 2003). In contrast, Japanese Black cows have been reported to produce milk at maximum of $6.0 \mathrm{~kg} /$ day at 10 days after parturition (SHIMADA et al., 1989). The milk yield of dams, however, may not have influenced upon the nutrient supply for calves in the first 7 days of their life because there were no significant differences in daily gain among groups with some variation. The amount of dam's milk intake by calves affected their growth for the first 2 months of age in Japanese Black calves (SHIMADA et al., 1993). Significant relations were recorded between the cow milk yield in the first $6^{\text {th }}$ months of suckling period and the daily weight gain (SCHOLZ et al., 2001). The variation observed in daily gain may have resulted from the difference in the amount of intake of dam's milk by an individual calf. This assumption is supported by the results of serum total cholesterol and triglyceride which also showed a large variation among individual calves, irrespective of their dam's breed. Blood glucose levels in neonatal normal calves of Japanese Black were reported to be $75.1 \pm 20.0 \mathrm{mg} / \mathrm{dL}$ and $114.7 \pm 20.0 \mathrm{mg} / \mathrm{dL}$ at their birth and 1 day of age, respectively (OGATA et al., 1997). The level of plasma glucose for calves in the present study showed the same change and also was in the same range as reported by OGATA et al. (1997). The level of serum total cholesterol was also within the range reported by OGATA et al. (1997). The level of plasma triglyceride was reported to be in the range from 22.9 to $54.3 \mathrm{mg} / \mathrm{dL}$ for calves of Brahman and its crossbred (GODFREY et al., 1991). The results of the present study were similar to those reported above, although the breed was not the same as in the present study. Therefore, calves in the present study were assumed to have obtained enough nutrient supply to support their growth in their first 7 days of life.

The calves in the present study were changed their nutrient supply from dam's milk to artificial milk replacer at 8 days of age without any adaptation period to mimic the Japanese calf nursery station system. Thus, the daily gain from 7 to 14 days of age was the lowest in the 60-day period in all groups. The level of serum triglyceride was also decreased to a level of less than $20 \mathrm{mg} / \mathrm{dL}$ in these periods, but thereafter, recovered to the level of about $30 \mathrm{mg} / \mathrm{dL}$. When Holstein bull calves were given 4 different kinds of milk replacer, significant differences were observed in the apparent digestibility of nutrients and apparent biological values of protein among the different kinds of milk replacer (TEROSKY et al., 1997). Thus, it is assumed that calves in the present study may have responded in a different way to abrupt change of liquid feed among groups and may have reduced the digestion efficiency in a different extent. The difference in response may have resulted in a decreased daily gain with different extent among groups. The period between 7 and 14 days of age, therefore, may be nutritionally a critical period for calves in a large scale nursery station.

OGATA et al. (1997) have reported that calves susceptible to disease were significantly smaller in weight at birth and had a lower daily gain compared to normal Japanese Black calves in days after birth. The birth weight of calves was in a normal weight range in the present study. TYLER et al. (1998) reported that optimal survival was observed in calves with a serum protein concentration over $5.5 \mathrm{~g} / \mathrm{dL}$. Calves in all groups in the present study showed a well exceeded level of serum protein over that 
reported by TYLER et al. (1998), except for those in the NC group. The level of apparent serum globulin was at the lowest values ranging from $1.7 \mathrm{~g} / \mathrm{dL}$ at 21 days of age to $1.9 \mathrm{~g} / \mathrm{dL}$ at 7 days of age for calves in the NC group. The serum immunoglobulin concentration of $1.5 \mathrm{~g} / \mathrm{dL}$ has been suggested to be a level which reduces health risks to dairy calves (BOYED et al., 1974; IRWIN et al., 1974). Activities of serum enzymes such as GGT were utilized to predict the concentration of immunoglobulin (PARISH et al., 1997; WILSON et al., 1999). By the prediction equation presented by WILSON et al. (1999), a GGT value over $1000 \mathrm{IU} / \mathrm{L}$ would have satisfied the level of immunoglobulin to reduce health risks. The results of the present study showed that the level of serum GGT was well over $1000 \mathrm{IU} / \mathrm{L}$ at the first day of life for all groups except the NC. From the results presented by PARISH et al. (1997), GGT values over $300 \mathrm{IU} / \mathrm{L}$ would have satisfied the level of immunoglobulin of $1.5 \mathrm{~g} / \mathrm{dL}$. WEAVER et al. (2000) reported that analysis of the results presented by TYLER et al. (1998) substantiated the majority of calves (77 \%) would have survived under conditions of complete failure of the passive transfer which was designated with serum protein concentrations less than $4 \mathrm{~g} / \mathrm{dL}$. The lowest level of serum protein was $4.2 \mathrm{~g} / \mathrm{dL}$ in the NC group at 7 days of age. This fact may support why calves in the NC group showed a fairly low frequency of any health disorders in their 60-day period. Calves that received dams' milk by bottle feeding for their first 3 days of life showed no significant difference in their health status from those suckled directly from their dams for their first 3 days of life (FRANKLIN et al., 2003). Thus, the bottle feeding of artificial colostrum is assumed to have no adverse effect on passive immune transfer, unless the artificial colostrum contains appropriate concentration of immunoglobulin. Therefore, calves in the present study were in good health with a low frequency of any health disorders, irrespective of the dam's breed. Levels of serum minerals for calves in all groups also support that they were in good health condition.

The concentration of immunoglobulin in colostrum produced by dams of different breeds ranged from $6.3 \mathrm{~g} / \mathrm{dL}$ for F1 dams to $10.2 \mathrm{~g} / \mathrm{dL}$ for Japanese Black dams. The colostrum from Holstein cows was reported to have the least level of immunoglobulin among breeds of dairy cows (MULLER and ELLINGER, 1981; TYLER et al., 1999). Assumed from the serum level of apparent globulin of calves in the present study, the concentration of globulin in colostrum for F1 dams and in artificial colostrum diluted by 3 times of warm water may satisfy a requirement of a calf to acquire passive immunity from the colostrum.

\section{Conclusion}

From results and discussion, it is concluded that there are no appreciable adverse effects of breeds of recipient dams on the performance of calves of Japanese Black produced by embryo transfer, provided some length of adaptation period was allowed to adapt calves to the artificial milk replacer. Also, there would be no appreciable adverse effect of commercial colostrum powder feeding on calf performance. The use of artificial colostrum powder, however, may require an elaborated method to ensure and sustain the passive immune transfer needed to reduce the risk of diseases, to maintain a calf healthy, and to increase daily weight gain. Thus, further study is needed to clarify the length of the adaptation period for changing the dam's milk to artificial milk replacer and to establish more elaborate artificial colostrums powder feeding methods. 


\section{References}

BESSER, T. E.; GAY, C.C.; PRICHETT, L.:

Comparison of three methods of feeding colostrum to dairy calves. J. Am. Vet. Med. Assoc. 198 (1991), 419-422

BOYD, J. W.; BAKER, J. R.; LEYLAND, A.:

Neonatal diarrhea in calves. Vet.Rec. 95 (1974), 310-313

BRAUN, J. P.; TAINTURIER, D.; LAUGIER, C.; BERNARD, J.; THOUVENOT, P.; RICO, A. G.:

Early variations of blood plasma gamma-glutamyl transferase in new born calves - A test of colostrum intake. J. Dairy Sci. 65 (1982), 2178-2181

BUCKLEY, F.; O’SULLIVAN, K.; MEE, J. F.; EVANS, R. D.; DILLON, P.:

Relationships among milk yield, body condition, cow weight, and reproduction in spring-calved Holstein-Friesians. J. Dairy Sci. 86 (2003), 2308-2319

FRANKLIN, S. T.; AMARAL-PHILLIPS, D. M.; JACKSON, J. A.; CAMPBELL, A. A.:

Health and performance of Holstein calves that suckled or were fand-fed colostrum and were fed one of physical forms of starter. J. Dairy Sci. 86 (2003), 2145-2153

GODFREY, R. W.; SMITH, S. D.; GUTHRIE, M. J.; STANKO, R. L.; NEUENDROFF, D. A.; RANDEL, R. D.:

Physiological responses of newborn Bos indicus and Bos indicus $\times$ Bos taurus calves after exposure to cold. J. Anim. Sci. 69 (1991), 258-263

GUY, M. A.; MCFADDEN, T. B.; COCKRELL, D. C.; BESSER, T. E.:

Regulation of colostrum formation in beef and dairy cows. J. Dairy Sci. 77 (1994), 3002-3007

IRWIN, V. C. R.:

Incidence of disease in colostrum deprived calves. Vet.Rec. 94 (1974), 105-106

JAPANESE MAFF:

Japanese Feeding Standard for Beef Cattle (2000). Agriculture, Forestry and Fisheries Research Council Secretariat ed. Japan Livestock Industry Association, Tokyo

MORIN, D. E.; MCCOY, G. C.; HURLEY, W. L.:

Effects of quality, quantity, and timing of colostrum feeding and addition of a dried colostrum supplement on immunoglobulin $\mathrm{G}_{1}$ absorption in Holstein bull calves. J. Dairy Sci. 80 (1997), 747-753

MULLER, L. D.; ELLINGER, D. K.:

Colostral immunoglobulin concentrations among breeds of dairy cattle. J. Dairy Sci. 64 (1981), 17271730

PARISH, S. M.; TYLER, J. W.; BESSER, T. E.; GAY, C. C.; KRYTENBERG, D.:

Prediction of serum IgG $_{1}$ concentration in Holstein calves using serum gamma glutamyltransferase activity. J. Vet. Intern. Med. 11 (1997), 344-347

OGATA, Y.; TAKAHASHI, K.; ABE, H.; MISAWA, T.; URUSHIYAMA, Y.; SAKAI, J.: Hematology and blood-biochemistry of weak Japanese Black calves. J. Jpn. Vet. Med. Assoc. 50 (1997), 589-592

ROBINSON, J. D.; STOTT, G. H.; DENISE, S. K.:

Effects of passive immunity on growth and survival in the dairy heifer. J. Dairy Sci. 71 (1988), 12831287

SCHOLZ, H.; KOVACS, A. Z.; STEFLER, J.; FAHR, R.-D.; LENGERKEN, G. v.:

Milk yield and milk quality of beef cows during the suckling period. Arch. Tierz., Dummerstorf 44 (2001), 611-620

SHIMADA, K.; IZAIKE, Y.; SUZUKI, O.; KOSUGIYAMA, M.:

Relationship between daily milk yield and suckling behavior in beef cattle. Jpn. J. Zootech. Sci., 60 (1989), 1071-1075

SHIMADA, K.; IZAIKE, Y.; SUZUKI, O.; OKANO, A.; TAKENOUCHI, N.; OHSHIMA, K.; OISHI, T.; KOSUGIYAMA, M.; TAKAHASHI, M.:

Research on milk yield and nursing ability in Japanese Black (Wagyu) cows. Bull. Chugoku Natl. Agric. Exp. Stn. 12 (1993), 57-123

STATITIX7:

User's manual (2000) Analytical Software, Tallahassee FL. USA.

STOTT, G. H.; MARX, D. B.; MENEFEE, B. E.; NIGHTENGALE, G. T.:

Colostral immunoglubulin transfer in calves. IV . Effect of suckling. J. Dairy Sci. 62 (1979), 1908-1913

TEROSKY, T. L.; HEINRICHS, A. J.; WILSON, L. L.:

A comparison of milk protein sources in diets of calves up to eight weeks of age. J. Dairy Sci. 80 (1997), 2977-2983

TYLER, J. W.; STEEVENS, B. J.; HOSTETLER, D. E.; HOLLE, J. M.; DENBIGH, J. L.:

Colostral immunoglobulin concentrations in Holstein and Guernsey cows. Am. J. Vet. Res. 60 (1999), 1136-1139 
TYLER, J. W.; HANCOCK, D. D.; WIKSIE, S. E.; HOLLER, S. L.; GAY, J. M.; GAY, C. C.: Use of serum protein concentration to predict mortality in mixed-source dairy replacement heifers. J. Vet. Intern. Med. 12 (1998), 79-83

WEAVER, D. M.; TYLER, J. W.; VANMETRE, D. C.; HOSTETLER, D. E.; BARRINGTON, G. M.: Passive transfer of colostral immunoglobulins in calves. J. Vet. Intern. Med. 14 (2000), 569-577

WILSON, L. K.; TYLER, J. W.; BESSER, T. E.; PARISH, S. M.; GRANT, R.:

Prediction of serum IgG $_{1}$ concentration in beef calves based on age and serum gamma-glutamyltransferase activity. J. Vet. Intern. Med. 13 (1999), 123-125

Received: 2004-01-23

Accepted: 2004-08-06

Author's addresses

Mr. AKIHIRO KURIHARA, MS.; Dr. TATSUYUKI SUZUKI, PhD

${ }^{1}$ United Graduate School of Veterinary Science, Yamaguchi University,

Yamaguchi 753-8515, Japan

Dr. JUNJIRO SEKINE, PhD; Dr. MITSUGU HISHINUMA, PhD

${ }^{2}$ Department of Veterinary Science, Faculty of Agriculture, Tottori University,

Tottori 680-8553, Japan

DR. TAKESHIGE OTOI, PhD

${ }^{3}$ Department of Veterinary Science, Faculty of Agriculture, Yamaguchi University,

Yamaguchi 753-8515, Japan

Corresponding author

Dr. MITSUGU HISHINUMA

Department of Veterinary Science, Faculty of Agriculture, Tottori University,

Tottori 680-8553, Japan

E-mail : mhishi@muses.tottori-u.ac.jp 